\title{
Impacts of Servant Leadership Style on Organizational Engagement of Employees Implications for Research on Leadership and Employee Engagement
}

\author{
Nguyen Anh Thu ${ }^{1, *}$, Duong Hong $\mathrm{Anh}^{2}$ \\ ${ }^{1}$ VNU University of Social Sciences and Humanities, 336 Nguyen Trai, Hanoi, Vietnam \\ ${ }^{2}$ VNU University of Languages and International Studies, Pham Van Dong, Cau Giay, Hanoi, Vietnam \\ Received 07 August 2017 \\ Revised 18 September 2017; Accepted 28 September 2017
}

\begin{abstract}
From a thorough examination of the relation between Servant leadership style and employees' organizational engagement, this study is conducted to theoretically evaluate how the style affects employees' organizational engagement. The paper is organized with three major sections: a review of the Servant leadership style and employees' organizational engagement, an analysis of its impacts on employees' organizational engagement, and implications for future research delving into this issue.
\end{abstract}

Keywords: Leadership styles, Servant leadership, Employee engagement, Organizational engagement.

\section{Introduction}

"How to achieve more for less in a sustainable way?" is a big question for any organization, especially for public organizations. This is because the answer for that helps to solve the dilemma faced by many organizations, which is to have to offer services at the highest standard while possessing limited resources [1]. One suggested solution as the answer is enhancing employee engagement with their job and organization. This derives from the positive influence of employee engagement on organizational outcomes, e.g.

\footnotetext{
* Corresponding author. Tel.: 84-24-35586013.

Email: nathu@ vnu.edu.vn

https://doi.org/10.25073/2588-1116/vnupam.4112
}

reducing employee turnover and improving organizational performance [2-4].

A question raised here is how to enhance employee engagement with their job and organization. There are several ways to address this question. One considerable factor that affects employee engagement is leadership style. Specifically, leaders/managers with a proper leadership style may motivate their employees to engage in useful activities contributing to organizational success [5]. Thus, determining and developing the styles which positively link to employee engagement have emerged into an attractive topic to both academics and practitioners.

Servant leadership style is not new but still interested by researchers because of its potential to improve employee engagement in the everchallenging context to organizations. The 
emergence of employees' need for supportive supervisors/managers/organization is considered as one of the key psychological needs of employees at work [6]. A leader can work as a servant in the way that they are always available to provide necessary supports and resources for their followers to work well. Once employees' needs are satisfied, their engagement can be enhanced.

Because of the rapid changes in most areas, leaders may not stick to only one certain style during their working life. It is important to look at different leadership styles to see their relationship with employee engagement in order to consider if and how they need to develop a proper leadership style for their subordinates and organization.

As a result, the purpose of this paper is to identify the link between servant leadership style and employees' engagement with their organization. The study will address two main research questions as follows:

- How can servant leadership style impact on employees' organizational engagement?

- What are the implications for the research on the impacts in the future?

To address the research questions above, the study will review the literature of leadership styles and employees' organizational engagement through the method of document analysis. Based on examining different perspectives and theories of leadership styles, particularly servant leadership style, as well as employees' organizational engagement, the study will infer how servant style can affect employee engagement with their organization and the implication of the influence for the future research.

\section{Overview of Leadership styles and Servant leadership style}

\subsection{Overview of leadership styles}

This section aims at reviewing the main perspectives and theories on leadership styles in order to determine where servant leadership style is positioned in the literature. Certainly, the section will provide details of servant leadership style so that readers can understand the link of the style to the remaining sections of the paper.

Starting with general understanding of leadership is to clarify the scope of the topic in this study. There have been different definitions of leadership. The variation of the definition is mainly semantic [7]. Thus, this study adopts a definition of leadership adapted from Kreitner (2009) and Naylor (2004) statements, which states that leadership is the process of inspiring, influencing and guiding other people towards achievement of organizational goals [7, 8].

Casimir (2001) claimed that "leadership style may be defined as a pattern of emphases, indexed by the frequency or intensity of specific leadership behaviors or attitudes, which a leader places on the different leadership functions" [9].

Historically, the most typical theories about leadership style include behavioural theories (style theories), situational/contingency model, and multidimensional analysis of leadership style.

Since the World War II, behavioural theories constructed leadership styles basing on a leader's behavior pattern [7]. Accordingly, main types of leaders' behaviors are the origins of leadership styles. For example, authority centralization and decentralization behaviours lead to authoritarian, democratic and laissezfaire styles (perspective of Universities of Iowa 1938); task-oriented and people-oriented behaviours produce initiating structure and consideration styles (studied by University of Michigan \& Ohio State 1951, cited from [10]); the behavioural patterns of concern for production and for people result in the leadership grid including impoverished management style (low in both concerns), country club management style (low in production concern, high in people one), authority-compliance style (high in production concern, low in the other, team management 
style (high in both concerns) and middle of the road management style (average of both concerns) [11].

However, behavioural models are criticized because a leader's style does not usually include only one component, but is also composed of both opposite components mentioned above [12]. Furthermore, to reflect the whole leadership style, the essentials of a leader's real conception, values, belief and preference need to be included in the style construction [13].

Based on an assumption that "no one best style of leadership exists" [7], situational or contingency theories propose three components of a leadership style, including leaders' traits, behaviours and situational factors [14]. It is important that for situational theorists, leaders' traits are internal qualities, namely personality, physical and mental characteristics, which are inborn for effective leaders. Contingency theorists do not emphasize the behavioural component because they focus on the flexibility of situations and the match between behaviours and situations to make successful leadership [7]. For instance, when situational factors, namely leader-member relation, task structure, position power, change, leaders can have taskoriented or people-oriented styles (Fiedler model 1967, cited from [14]); or contingency factors such as the impact of decision on performance, the willingness of the followers to accept the decision and the time needed to make the decision vary, the leader's style can be autocratic or consultative or group (Vroom \& Yetton, cited from [8]).

Nevertheless, contingency theories have been questioned whether a leader's style remains when his/her context changes or not. Hence, it is claimed that situational factors should not be included as a component of leadership style [15]. However, the appearance of situational factors in leadership styles reflects the ever-changing status of society and organizations. Thus, it should be considered as a factor affecting how to choose a suitable leadership style.
Continuing to focus on contextual changes within organizations and wider, James McGregor Burns (1978) proposes transformational leadership style which is a style possessed by visionaries "who challenge people to achieve exceptionally high level of morality, motivation, and performance" (cited from [7]). Burns even claims that only transformational leaders are able to master changes as one of the key characteristics of modern organizations. Charisma is an attribute added to transformational style to emphasize the special power of transformational leaders in inspiring their subordinates to do the unexpected, above and beyond the plan [7]. Besides, transactional style which is to focus on motivating people to do the expected plan is also necessary for organizations today [7].

From the literature, servant leadership style has been proposed related to the perspectives focusing on ethical, moral, and spiritual leadership. This is because, over the time, the changes in society and organizations from short-term and personal bonus oriented to longterm societally responsible focus ask people to think about a sustainable leadership way by which employees/followers are as respected as and by their leaders [16].

\subsection{Overview of Servant leadership style}

The term servant leadership was first coined by Greenleaf (1977) who defined it as follows: "The servant leader is servant first. It begins with a natural feeling that one wants to serve, to serve first. Then conscious choice brings one to aspire to lead." [17]. By saying that, he emphasizes the willingness and desire to serve as the fundamental characteristic of a servant leader who can gain leadership skills through serving their followers.

The philosophy was stimulated and clarified with sets of servant leader attributes or multidimensional measures of servant leadership under different frameworks. Spears (1998) typified ten different qualities of a servant leader including: listening, empathy, 
healing, awareness, persuasion, conceptualization, foresight, stewardship, commitment to the growth of people, and building community [18]. Page and Wong (2000) named empowering and fostering followers, humility, service, vision, integrity, sincerity, participative and inspirational elements as characteristics of servant leadership [19]. According to Covey (2002), a servant leader is required to possess following characteristics: humility, reverence, openmindedness, eagerness for learning, respectfulness, helpfulness, and determination [20]. In Patterson's (2003) study, seven factors were concluded to construct a servant leader, namely humility, altruism, vision, trust, empowerment, service, and follower's agape [21]. It can be generalized that abovementioned traits of servant leadership are basically based on "behavioral, relational, and emotional concepts" [22].

Instead of focusing on identifying behavioral characteristics of servant leadership, $\mathrm{Ng}$, Koh, \& Goh (2008) switched the centrality to motivation to serve as the driving force behind as well as impacts on such leadership behaviors, aligned with the core of Greenleaf's (1977) philosophy of servant leadership [23]. It is concluded that "motivation-to-serve is a construct that exhibits both trait-like as well as state-like attributes", which means individual personalities, value orientations, and experience with servant leaders decide the willingness to serve of a leader. To be more specific, agreeableness, conscientiousness, neuroticism, self-enhancement values, self-transcendent values, and experience with servant leaders exert significant impacts on individual servant leadership behaviors. Furthermore, the empowering climate of an organization is claimed to be a situational moderator that enables or discourages individual's motivation-to-serve.

In general, servant leadership represents a model of leadership in which the balance between morality, mission achievement, and promoting the best interests and wellbeing of the key stakeholders (employees, organization, and community) is underlined [24].

To serve the purpose of examining the impacts of Servant leadership on Organizational Engagement of Employee, the multidimensional set of servant leadership behaviours proposed by Ekinci (2015) was adopted as the core model in this study. Five attributes of a servant leader is described as follows:

Empathy: According to Spears (2004), empathy requires the leader to form the perspective of appreciating each employee's value and caring about their needs and feelings [25]. It includes key elements such as helping, active listening, sharing, social interactions, and other altruistic behaviours. Such factors help avoiding misunderstanding, miscommunication, and misconceptions among members of an organization.

Altruism: Altruistic behaviours, the basis of servant leadership approach, are based on the leader's willingness to serve the followers, focus on their needs and expectations, help solving their problems [17]. Altruism adjures the leader to set a model of respecting group benefits and serving others, rather than being selfish and purely giving orders and commands. As a result, it will exert positive effects on organizational processes such as "worker's commitment, sense of belonging, and dedication" [26].

Humility: It is considered one of the most important and significant qualities of a servant leader because humble attitudes and behaviours can resolve the "social borders in communication" between leaders and followers, generate "sincerity and respect to grow", and engage employees basing on "internal commitment" [21].

Integrity: One of the most striking features distinguishing servant leadership from other leadership approaches is its emphasis on morality. The leader's consistency and commitment to ethical values engender sincerity, build trust, and enable acceptability in 
the follower towards the leader and the organization $[17 ; 27 ; 28]$.

Justice: Servant leaders necessarily acknowledge rights of individuals and manifest fairness "in the organizational process with tasks, sharing of sources, and evaluation of workers" [22].There exists evidence of correlation between justice and employees' "acceptance of sacrifice, commitment, and dedication" [29-31].

This framework bears some advantages compared with previous models because overlapping attributes in Spears' (1998), Page and Wong's (2000), Covey's (2002), and Patterson's (2003) can be avoided. Moreover, Ekinci's (2015) model was employed in thoughtful consideration of educational context where moral values are expected to be more highlighted [22]. This correlates with the central focus of servant leadership which emphasizes ethical aspects.

\subsection{Servant Leadership and Related Leadership Theories}

In comparison with other idealized concepts of leadership, servant leadership shares some common traits such as: role modeling, inspirational communication, and altruism [32]. However, servant leadership bears important differences from related leadership theories.

Primarily, morality is one of the main components of servant leadership while it is not included in popular leadership theories, namely charismatic and transformational leadership [33]. According to Wart (2003), servant leadership is identified as the first theory that highlights ethical orientation of leadership [34]. In recent research, the concept of ethical leadership centering moral and ethical values in leadership behaviour has emerged [32]. Kaptein et al. (2005) claimed that ethical leaders can influence followers more positively, which is exhibited in the results of their actions and the overall ethical condition of an organization [35].
Second, one striking factor that makes servant leadership distinctive is the priority of followers' individual growth and development [36]. The commonly-shared focal behavior of other leadership styles is inspiring and engaging followers as a means to accomplish missions by connecting individual values of the follower with common goals of the organization [33]. More importantly, the needs and interests of stakeholders including employees, organization, and community are seriously considered in servant leadership. Servant leaders lead through service, instilling followers' voluntary commitment, cooperation, and responsibility.

Finally, self-reflection to attenuate the leader's hubris is necessary for a servant leader [37] while it is a behavior excluded in authentic, ethical, and transformational leadership.

Traditional leadership models prioritizing corporate goals in the short term was suitable in the period of industrialization when employees were considered as a means to achieve organizational goals, but "has limitations in this period that requires continuous high performance" [16]. Therefore, servant leadership, with sustainability-focused approach and its above-mentioned distinguishing features explains the proliferation of empirical studies in the field of servant leadership.

\section{Impacts of servant leadership style on employees' organizational engagement}

\subsection{Overview of employees' organizational engagement}

Employee engagement is defined in different ways. Most of the definition considers engagement as job or work engagement.

One of the most widely-referenced definitions states that job/work engagement is described as the psychological presence of employees. Specifically, it refers to "a positive, fulfilling, work-related state of mind that is 
characterized by vigor, dedication, and absorption" [38]. Vigor can be described as "high level of energy and mental resilience while working"; dedication involves one's strong feelings of significance, enthusiasm, and challenge; and absorption refers to one's "being fully immersed in their work" [39].

However, some authors differentiate job engagement and organizational engagement. Based on the distinction, Meyer et al. (2010:64, cited in [40]) offered a working definition as follows: "Engagement is experienced as enthusiasm and self-involvement with a task or collective (e.g., organization), is fostered by a corresponding dispositional orientation and facilitating climate, and manifests itself in proactive value-directed behavior". In short, one's organizational engagement mainly involves their enthusiasm and self-involvement with their organization. Saks (2006) emphasizes that organizational engagement relates to one's attachment to their organization no matter what their work role is [41].

It is noted again that this paper examines the link between servant leadership style and employees' organizational engagement, not job engagement or organizational commitment.

It is important to differentiate organizational commitment from organizational engagement. The former refers to "a person's attitude and attachment towards their organization" [41]. The latter is not an attitude, but "it is the degree to which an individual is attentive and absorbed in the performance of their roles" [41]. The former focuses on employees' extra role and voluntary behaviours while the latter emphasizes the employee formal role performance [41].

As a result, organizational engagement has been constructed with two factors: organizational vigor and organizational dedication [42]. The first component refers employees' high level of employee energy, inspiration, strength and joy in their workplace [43; 44]. Specifically, this factor is characterized by the feeling of being alive, exhilarating, captivating and inspired by the organization as a member of the organization. Additionally, employees will possess the feeling of being strong and energetic when working in their organization as well as a motivation to do the organizational works at the highest level [42].

The second factor involves employees' willingness to invest their discretionary effort to solve organizational problems, make recognized contribution to organizational success, and protect their organization from injustice (Schneider, Macey, Barbera \& Martin 2009; Vance 2006; cited in [42]).

Meyer (2014) distinguishes three types of organizational engagement, including disengagement, contingent engagement, and full engagement [40]. Disengaged employees seem to have little commitment to their organization and to be convenient to quit the organization; contingently engaged people have highly continuance involvement with their organization because of the exchange benefits they receive from their organization or lack of opportunities with other employers, rather than thanks to their voluntary and positive feeling of attachment to the current organization; and fully engaged employees possess strong affective and/or normative commitment with the feeling of moral duty to contribute to organizational goals [40].

Within the ever-changing environment as today, organizations must develop solutions to move their entire staff to full engagement [40]. Clarifying possible positive influences of leadership in general, and servant leadership style in particular, on the components of employees' organizational engagement can suggest leaders/managers in practice how to enhance their subordinate organizational engagement.

\subsection{Impacts of servant leadership style on employees' organizational engagement}

To get employees fully engaged, organizations have to satisfy employees' basic 
psychological needs at work (BPNW) [40]. BPNW includes three needs, namely autonomy, competence and relatedness. Autonomy refers to the need for having power to make decision and to act in one's own way [45]. This need is characterized by the extent to which a person can make their own decision, use their judgement and their own ways to do their job, as well as take responsibilities in their work [6].

Competence involves one's feeling of having knowledge, skills and supported resources to do their job well (White 1959, cited in [46]). This need can be measured by the extent of how available individual and organizational resources are for a person to complete their job at high standard.

Relatedness is the need for the feeling of belonging to a working community (Baumeister \& Leary 1995, cited from [47]). This need focuses on how employees feel being trusted, understood, listened, being a friend with and supported by their colleagues at work [6].

Following Meyer's claim of the importance of employee need satisfaction in enhancing their organizational engagement, in this paper, the impacts of servant leadership style on employee organizational engagement will be drawn on the way that servant leadership can satisfy each of the basic psychological needs at work of employees. As such, the basic psychological needs at work play a mediating role in the relationship between servant leadership style and employee organizational engagement. This is modeled in Figure 1.

Generally, servant leaders with the characteristic of altruism will take good care of their followers' needs, expectation and problems [48]. This means they tend to position themselves in their employees' circumstance to understand the employees' needs for autonomy, competence and relatedness in order to try to satisfy the needs. By this way, employees can feel being satisfied, respected, alive, and exhilarating when they work in the organization. Furthermore, servant leaders will not be selfish but they focus on serving others, thus, they will motivate their subordinates' dedication to the organization [26]. As a result, the employee organizational engagement will increase.

Servant leaders who are highly empathetic will focus on their relationship with their subordinates, active listening and social interactions (Spears 1998, cited in [22]). Because of active listening, servant leaders will avoid misunderstanding, misconceptions and problems with communications at work [49]. Therefore, they can understand exactly the messages in the communications. Additionally, thanks to the leaders' respect of collaborative relationship and interactions with their coworkers/subordinates, they tend to build up the relationship/interactions rather than dictatorially asking the followers to complete tasks. Thus, servant leaders can understand the subordinates' needs and expectations, and be partners/supporters to solve the followers' problems. It is confirmed that "perceived organizational support predicts both job and organization engagement" [41]. This leads to the increase in employees' feeling of being understood and cared by important people in the organization and create respectful working environment, meaning that the employees' need for relatedness is fulfilled [50]. By this way, servant leaders will make employees satisfied and exhilarating when being the organizational member (a dimension of organizational vigor); and motivate them to contribute to the organizational goals (an element of organizational dedication). Like altruism characteristic, this will contribute to the positive changes of employees' organizational commitment.

Humility is another important characteristic of servant leaders which may impact significantly on employees' organizational engagement. This is because humility helps the leaders remove any barriers between them and their followers leading to a closer cooperation to obtain their shared goals [22]. Being not arrogant and selfish, leaders can encourage their subordinates to raise ideas and use their own 
proper and effective judgement and ways to do the job. This means employees' need for autonomy is considered and satisfied. This also relates to the need for relatedness which emphasizes the feeling of being understood and trusted. Therefore, servant leadership can help employees feel strong and energetic when being autonomous at work and motivate them to do their best in order to solve organizational problems and contribute to organizational success. This means employees' engagement can be enhanced by the characteristic of humility of servant leadership style.

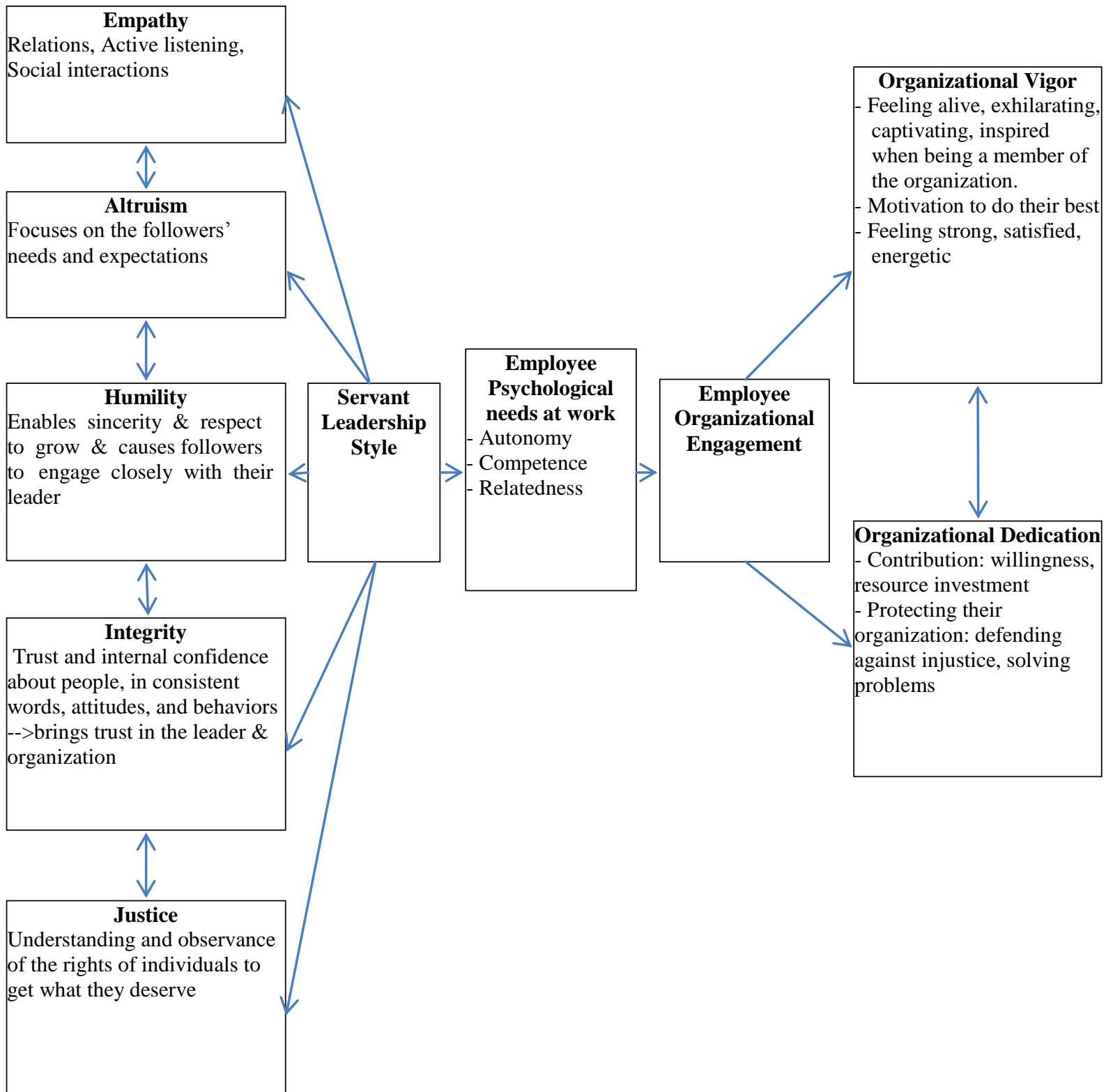

Figure 1. Model of impact of servant leadership style on employees' organizational engagement. 
Integrity is thought to be one of the factors that impact most on employees. This is because servant leaders with integrity can make employees trust the organizational management so that they can be reassured about a moral work environment. By honest behavior, servant leadership can encourage their subordinate develop the same behavior and attitude (Cassel $\&$ Holt 2008, cited in [22]), leading to a mutual trust between the leaders and their followers. This contributes to satisfy employees' need for relatedness of which focuses on the feeling of being trusted and being a friend of their coworkers. This may support to the employee feeling of being alive, exhilarating and satisfied as an organizational member. This results in a willingness of employees to contribute to their organization. Thus, their vigor and dedication will be enhanced.

Integrity is usually accompanied by justice. These dimensions support each other in creating ethical work environment. Moral climate, in turn, forms the way that ethical decisions should be made and behaviours should be developed within an organization [51]. As described earlier, servant leaders with justice characteristic will understand and obey the rights of employees to get what they deserve (Cevizci 2010, cited in [22]). In other words, servant leaders see equality, fairness and respect for employees as core values of their leadership activities.

At work, justice will be mainly expressed in being fair in sharing/allocating resources, evaluating performance [22] and rewarding. Specifically, servant leaders will be rational to provide how much resource among their department in order to ensure that all employees can do their job well. Additionally, during the process of performance appraisal and reward, the key criterion should be employees' contribution to organizational success rather than other ones like relationship with managers or ages. This procedural justice can predict organizational engagement [41].

Leaders' justice along with integrity will satisfy not only the need for relatedness through making employees' feel being trusted and being a friend of their co-workers, but also the need for competence which refers to being able and competent to complete the job well. This is because that employees always have a need to sufficiently control their resources and their job in order to succeed (Maslach et al. 2001, cited in [50]). Hence, Saks (2006) advises that managers should determine the resources and benefits that employees desire most to try to provide them to get the employees higher engaged [41].

The two characteristics of servant leadership above will motivate employees to be willing to do their best at work and defend against injustice (organizational vigor and dedication) leading to employees' full engagement. Therefore, Malinen, Wright \& Cammock (2013) claim that trust in management and perceived justice are important drivers of employees' organizational engagement [52].

In summary, servant leaders possess at least five out of ten critical leadership capabilities which are essential to engaging employees (Taylor 2004, cited in [51]), including building trust, building esteem, communicating effectively, building an enjoying and fulfilling work environment, and flexibility in understanding individual needs. Thus, theoretically, servant leadership can be a considerable style to improve employees' organizational engagement.

\section{Implications for future research on servant leadership and employee engagement}

The section will draw the implications for future research on the topic from the approach to the impact of servant leadership style on employees' organizational engagement, the challenges of the style itself, and the limitation of previous studies and this study.

First of all, the model of the impact expresses an emerging approach to examine the relationship between servant leadership style 
and employee engagement with their organization, which is using need satisfaction as a media factor to connect the two objects. This approach appears from Self Determination Theory in which the three basic psychological needs at work are central concepts. Under the theory, the better the needs are satisfied, the higher the employee internal motivation is [40], leading to the higher level of their engagement at work. This is the rationale for Meyer's claims (2014) that organizations should meet the employee needs to get them fully engaged. This expresses a logical approach to the influence of organizational factors (servant leadership style in this case) on employee engagement with their job and organization. Meanwhile there has been a lack of works on the topic from this approach, it has been potential for future research using the approach to investigate more deeply the impact.

The positive impacts show that servant leadership style is a promising style which can help organizations solve problems regarding to employee engagement. However, the style itself embeds challenges for both academic and practitioners. Therefore, the second implication is that future research can focus on solutions to overcome the challenges. Wilson (1998) summarized three potential difficulties a servant leader may have to face [53]. First, being an empathetic individual is challenging for leaders when it requires them to be a true listener and empathize with others. In fact, it is not easy for leaders to well complete the roles of listening and empathizing. Another difficulty comes from the integration of being empathetic and collaborative, which entails sharing something of himself or herself with others. This requirement asks leaders to be really openminded to respect employees as their team members or partners rather than their subordinates who are always at the lower level to do what the leaders tell. The third challenge revolves around collaborative process because the involvement of many people with different viewpoints, values, personalities in such processes requires great patience and perseverance of the leader. From that, future research can look at the ways to enable leaders to be a true listener and to really empathize; as well as solve the conflicts among different stakeholders' characteristics to ensure that servant leadership can be realized.

Apart from the potential challenges, the previous researches of servant leadership received certain criticisms. Greenleaf (1977), who first coined the term servant leadership, revealed that this concept was too ideal to be applied in reality [17]. Moreover, the word 'serve' has not been specifically defined, which explains the lack of agreement in defining the concept of servant leadership. Furthermore, a need for reconstruction of verifiable models "by developing measurement scales and extracting elements in the reality" was raised by Kim, Kim, \& Choi (2014) who claimed that although servant leadership is empirically useful, its academic acknowledgement is deterred [54]. These challenges may hinder leaders/managers from applying the style in practice. This may result to a higher level of difficulty to convince the practitioners about the value of servant leadership style no matter how much useful the style is in theory. Hence, future research can focus on the measurement of servant leadership style. This will facilitate how to measure the impact of servant leadership style on employees' organizational engagement. From the literature, empirical studies to examine the correlation between servant leadership and employee engagement are in special need and highly recommended. By this way, it may be easier to look for empirical evidence of the influence in order to better convince leaders of applying this style and be more attractive to academics.

Despite certain significance, our study still remains some limitation. Primarily, even though the difficulties in implementing servant leadership, solution to address the abovementioned challenges has not been proposed within the limited scope of this study. The main reason is that this study presents those problems in pure theoretical context basing on literature 
review rather than empirical data or evidence. It is more critical for the correlation between servant leadership and organizational engagement of employees to be empirically studied due to the lack of research in this issue. Finally, the need for a reconstruction of servant leadership model in relation with organizational engagement has not been met and leaves a consideration gap for further research. This continues to confirm that developing empirical studies on the topic will be interesting focus for future research.

Additionally, how a set of criteria for moral and ethical aspects can be applied in evaluating servant leadership remains a question of debate. This suggest researchers to build the comprehensive criteria to support the process of measuring the impact of servant leadership style on employee engagement with their organization.

Last but not least, the scope of further studies can be either broaden to the extent of servant leaders' impacts on full aspects of employees' engagement specified in certain contexts and areas such as in higher education in Vietnam or in organizations in both public and private sectors in Vietnam so as to ponder and propose implications for particular fields.

\section{Conclusion}

In general, leadership factors are closely correlated with employee engagement because circumstances, including organizational environment, leadership characteristics, job characteristics, under which "some would actively engage while others would actively disengage are particularly relevant to both the employer and the employee" [50]. Servant leaders are theoretically proved to exert positive impacts on organizational engagement of employees, with five key characteristics (empathy, altruism, humility, integrity, and justice) exhibited in five important capabilities to engage employees including building trust, building esteem, communicating effectively, building an enjoying and fulfilling work environment, and flexibility in understanding individual needs. Thanks to such attributes of a servant leader, three basic psychological needs at work, namely autonomy, competence and relatedness, are satisfied, creating positive changes of employees' organizational commitment and increasing their willingness of devotion and dedication. However, the impacts discussed in this study requires empirical evidence, can be examined through need satisfaction approach, and should be studied in specific contexts like higher education or organizations in public sector. Furthermore, measurements of moral and ethical aspects of servant leadership, reconstruction of a servant leadership model, and solution addressing challenges in servant leadership implementation are potential subjects for further studies./.

\section{References}

[1] Storey, J. (editor) (2016), Leadership in Organizations. Current issues and key trends, $3^{\text {rd }}$ edn, Routledge, NY.

[2] Gorgievski, M.J., Bakker, A.B. \& Schaufeli, W.B. (2010), "Work engagement and workaholisim: comparing the self-employed and salaried employees", The Journal of Positive Psychology, vol. 5, pp. 83-96.

[3] Rich, B.L., LePine, J.A., Crawford, E.R. (2010), "Job Engagement: Antecedents and Effects on Job Performance", Academy of Management Journal, vol.53, no.3, pp.617-635.

[4] Chunghtai, A.A. \& Buckley, F. (2011), "Work engagement antecedents, the mediating role of learning goal orientation and job performance.", Career Development International, vol.16, no.7, pp.684-705.

[5] Łukowski, W. (2017), “The Impact of Leadership Styles on Innovation Management", Minib (Marketing of Scientific and Research Organizations), vol.24, no.2, pp.105-136.

[6] Brien, M., Forest, J., Mageau, G.A., Boudrias, JS., Desrumaux, P., Brunet, L. \& Morin, E.M. (2012), "The Basic Psychological Needs at Work Scale: Measurement Invariance between Canada and France", Applied Psychology: Health and Well-Being, vol.4, no.2, pp.167-187. 
[7] Kreitner, R. (2009), Principles of Management, International Student Edition, $11^{\text {th }}$ edn, SouthWestern Cengage Learning, Australia, p.436, 440, $443,445,446$.

[8] Naylor, N. (2004), Management, $2^{\text {nd }}$ edn, Pearson Education, England, p.355, 364.

[9] Casimir, G. (2001), "Combinative aspects of leadership style: The ordering and temporal spacing of leadership behavior", The Leadership Quarterly, vol.12, no.3, p.246.

[10] Robbins, S., Bergman, R., Stagg, I. \& Coulter, M. (2006), Management, 4th edn, Pearson Prince Hall, Frenchs Forest, NSW, p.570.

[11] Blake, R.R. \& Mouton, J.S. (1964), The Managerial Grid III, Gulf Publishing, Houston, p.136.

[12] Monica E.L. (1986), Nursing Leadership and Management. An Experiential Approach, Jones and Bartlett Publisher, USA, p.65.

[13] Saxena P.K. (2009), Principles of Management: A Modern Approach, Global India Publications Pvt Ltd, New Delhi, p.127.

[14] Horner, M. (1997), "Leadership theory: past, present and future", Team Performance Management, vol.3, no.4, p.271.

[15] Nguyen, Anh Thu (2016), "Influences of Leadership Style on Talent Retention. Implications for the Public Universities in Vietnam", VNU Journal of Science, Social Sciences and Humanities, ISSN 0866-8612, vol.32, no.1, p.69.

[16] Yukl, G. (2006). Leadership in Organizations. Upper Saddle River, NJ: Pearson Prentice Hall.

[17] Greenleaf, R. K. (1977). Servant leadership: A journey into the nature of legitimate power and greatness. New York: Paulist Press, p.27.

[18] Spears, L. (1998). Insights on leadership: Service, stewardship, spirit, and servant leadership. New York: Wiley.

[19] Page, D., \& Wong, T. P. (2000). A philosophy conceptual framework for measuring servant leadership. In S. Adjibolosoo (Ed.), The Human factor in shaping the course of history and development. Lanham, MD: University Press of America.

[20] Covey, S. (2002). Servant-leadership and community leadership in the twenty-first century, in Spears, L. (Ed.). Focus on Leadership: Servant Leadership for the 21st Century. New York: Wiley.

[21] Patterson, K. (2003). Servant leadership: A theoretical model. Dissertation Abstracts International, 64(2), 570 (UMI No. 3082719).
[22] Ekinci, A. (2015), "Development of the School Principals' Servant Leadership Behaviors Scale and Evaluation of Servant Leadership Behaviors According to Teachers' Views", Education and Science, vol.40, no.179, pp.341-360.

[23] Ng, K.-Y., Koh, C., S.-K., \& Goh, H.-C. (2008). The heart of the servant leader. Leader's motivation-to-serve and its impact on LMX and subordinates' extra-role behavior. In G. B. Graen \& J. A. Graen (Eds.), Knowledge-driven corporation-complex creative destruction: 125144. Charlotte, NC: Information Age.

[24] Roberts, G. (2014). Servant leader human resource management - A moral and spiritual perspective. New York: Palgrave Macmillan US.

[25] Spears, L. C. (2004). Practicing servantleadership. Leader to Leader, 34, 7-11.

[26] Avolio, B. J., \& Locke, E. E. (2002). "Philosophies of leader motivation: Altruism versus egoism". Leadership Quarterly, 13(2) 169-191.

[27] Cassel, J. \& Holt, T. 2008. The servant leader. American School Board Journal October: 34-35.

[28] Joseph, E. E., \& Winston, B. E. (2005). A correlation of servant leadership, leader trust, and organizational trust. Leadership \& Organization Development Journal, 26(1), 6-22.

[29] Konovsky, M. A., \& Pugh, D. S. (1994). Citizenship behavior and social Exchange. Academy of Management Journal, 37(3), 656-669.

[30] Niehoff, B. P., \& Moorman, R. H. (1993). Justice as a mediator of the relationship between methods of monitoring and organizational citizenship behavior. Academy of Management Journal, vol. 36(3), pp.527-556.

[31] Organ, D. W. (1990). The motivational basis of organizational citizenship behavior. Research in Organizational Behavior, 12, 43-72.

[32] Brown, M.E., \& Treviño. L.K. (2006). Ethical leadership: A review and future directions. Leadership Quarterly, 17(6), 595-616.

[33] Bass, B.M. (1985). Leadership and Performance beyond Expectations. New York: The Free Press.

[34] Wart, M.V. (2003). Public-sector leadership theory: An assessment. Public Administration Review, 63(2), 214-228.

[35] Kaptein, M., Huberts, L., Avelino, S., Lasthuizen, K. (2005), Demonstrating ethical leadership by measuring ethics: A survey of US public servants. Public Integrity, 7(4), 299-311.

[36] Smith, B.N., Montagno, R.V., and Kuzmenko, T.N. (2004). Journal of Leadership and Organizational Studies, 10(4), 80-91. 
[37] Graham, J. (1991). Servant-leadership in organizations: Inspirational and moral. Leadership Quarterly, 2(2), 105-119.

[38] Schaufeli, W.B., Martínez, I.M., Pinto, A.M., Salanova, M. \& Bakker A.B. (2002), "Burnout and Engagement in University Students. A CrossNational Study", Journal of Cross-Culture Psychology, vol.33, no.5, p.474.

[39] Kanten, S. \& Sadullah, O. (2012), An empirical research on relationship quality of work life and work engagement, Procedia - Social and Behavioral Sciences, vol.62, p.362.

[40] Meyer, J.P. (2014), Employee Commitment, Motivation and Engagement: Exploring the Links in Gagné, M. (2014) (ed.), The Oxford handbook of work engagement, Motivation, and SelfDetermination Theory, Oxford University Press.

[41] Saks, A.M. (2006), 'Antecedents and consequences of employee engagement', Journal of Managerial Psychology, vol. 21, no.7, pp.600-619.

[42] Ünal, Z.M. (2015), “The Buzzword: Employee Engagement. Does Person Organization Fit Contribute to Employee Engagement?", Iranian Journal of Management Studies (IJMS), vol.8, no.2, pp.157-179.

[43] Albrecht, S. L. (2010). Handbook of Employee Engagement Perspectives, Issues Research and Practice, Edward Elgar, Cheltenham, UK.

[44] Macey, W. H. \& Schneider, B. (2008). "The meaning of employee engagement". Industrial and Organizational Psychology, vol.1, pp.3-30.

[45] Gagné, M. \& Deci, E. (2005), "Self-determination theory and work motivation", Journal of Organizational Behavior, vol.26, pp.331-362.

[46] Van den Broeck, A., Vansteenkiste, M., Witte, H.D., Soenens, B. \& Lens,W. (2010), "Capturing autonomy, competence, and relatedness at work: Construction and initial validation of the Workrelated Basic Need Satisfaction scale", Journal of
Occupational and Organizational Psychology, vol.83, p.1198.

[47] Schreurs, B., Hetty van Emmerik, IJ., Van den Broeck, A. \&, Guenter, H. (2014), "Work Values and Work Engagement Within Teams: The Mediating Role of Need Satisfaction", Group Dynamics: Theory, Research, and Practice, vol.8, no.4, pp.267-281.

[48] Sendjaya, S., \& Cooper, B. (2011). "Servant leadership behaviour scale: a hierarchical model and test of construct validity". European Journal of Work and Organizational Psychology, 20(3), 416-436.

[49] Degraaf, D. G., Tilley, C., \& Neal, L. L. (2001). Servant-Leadership Characteristics In Organizational Life. Voices of ServantLeadership Series, Booklet (6). Indianapolis: Greenleaf Center for Servant-Leadership.

[50] Wildermuth, C.M.S. \& Pauken, P.D. (2008), “A perfect match: decoding employee engagement Part I: Engaging cultures and leaders", Industrial and Commercial Training, vol.40, no.3, pp.122128.

[51] Taghipour, A. \& Dezfuli, Z.K. (2013), Designing and Testing a Model of Antecedents of Work Engagement, Procedia - Social and Behavioral Sciences, vol.84, p.145.

[52] Malinen, S., Wright, S. \& Cammock, P. (2013), "What drives organisational engagement? A case study on trust, justice perceptions and withdrawal attitudes", Evidencebased HRM: A Global Forum for Empirical Scholarship, vol.1, no.1, pp. 96-108.

[53] Wilson, R. T. (1998). Servant leadership. The Physician Executive, 24(5), 6-13.

[54] Kim, S.J., Kim, K.S, Choi Y.G. (2014). A literature review of servant leadership and criticism of advanced research. International Scholarly and Scientific Research \& Innovation, 8(4), 1154-1157. 


\title{
Tác động của phong cách lãnh đạo Người phục vụ tới sự gắn kết của nhân viên với tổ chức Một số gợi ý đối với các nghiên cứu về lãnh đạo và sự gắn kết của nhân viên
}

\author{
Nguyễn Anh Thư ${ }^{1}$, Dương Hồng Anh ${ }^{2}$ \\ ${ }^{I}$ Truoòng Đại học Khoa học Xã hội và Nhân văn, ĐHQGHN, 336 Nguyến Trãi, Hà Nội, Việt Nam \\ ${ }^{2}$ Truờng Đại học Ngoại ngũu, ĐHQGHN, Phạm Văn Đồng, Cầu Giấy, Hà Nội, Việt Nam
}

Tóm tắt: Qua việc xem xét mối quan hệ giữa phong cách lãnh đạo Người phục vụ và sự gắn bó của nhân viên với tổ chức, bài viết nhằm đánh giá trên lý thuyết ảnh hưởng của phong cách lãnh đạo này đến sự gắn bó của nhân viên với tổ chức. Theo đó, bài viết sẽ đề cập đển ba nội dung chính, gồm tổng quan về phong cách lãnh đạo Người phục vụ và sự gắn bó của nhân viên với tổ chức; phân tích tác động của phong cách này đối với sự gẳn bó của nhân viên dành cho tổ chức; và đưa ra gợi ý cho các nghiên cứu về mối quan giữa hai yếu tố này trong trong tương lai.

Từ khóa: Phong cách lãnh đạo, Lãnh đạo kiểu Người phục vụ, Sự gắn kết của nhân viên, Gắn kết với tổ chức. 